\title{
THE EFFECTIVENESS OF USING SONGS IN TEACHING LISTENING SKILL AT THE SECOND GRADE OF SMP N 11 KABUPATEN SORONG
}

\author{
Nurteteng \\ teteng.syaid72@gmail.com \\ Doni Sudibyo \\ donisud@unimudasorong.ac.id \\ Karolina Feni Kolin \\ Karolinefeni@gmail.com
}

Education University of Muhammadiyah Sorong, Indonesia

\begin{abstract}
The use of song in the classroom can stimulate very positive associations to the study of a language. They can also make the classroom situation more enjoyable for students and increase the students' interest to learn. Songs are chosen here because many of the students had listened to it. It can stimulate their motivation to learn, and to help the students learn English especially Listening Skill.The problem of this research can be stated how is using song effective in teaching listening skill at the second grade of SMP N 11 Kabupaten Sorong. The objectives of this study is to know effective or not using song in teaching listening skill at second grade of SMP N 11 Kabupaten Sorong. The study was conducted at SMP N 11 Kabupaten Sorong. The subjects of this study were the students at the second grade of SMP N 11 Kabupaten Sorong in two classes thus were as experimental and control groups. The numbers of the subjects were 24 students in experimental class (10 male and 12 female) and 24 students in control class (14 male and 10 female). This research used experimental method. The techniques of data collection used by the researcher are observation, and test (pre-test and post-test).Based on the statistical data, the researcher got a description that the results of test score of the experimental class which was given treatment using songs as media was 74.583 and control class which did not get treatment using songs as media that was 62.917. Based on the t-test with standard of significant $5 \%$, it was found $=3.213$ with $t$-table $=2.021$ Consequently based the result, the process of learning Listening using songs as media is effective. In conclusion, there is a real difference in score between those who using song as media and those who learn without using songs as media. In another word, the process of learning Listening using songs as media is effective.
\end{abstract}

Key Words: Teaching Listening Skill, Song

\section{INTRODUCTION}

English has been becoming a compulsory foreign language in Indonesia. It is one of the subjects that is taught since in the Elementary school until university and examination in the national examination to determine student's graduation. English has four skills such as listening, reading, writing and speaking. Listening skill become the first foundation that have to understand by student. Listening skill become the basic skill for expand another skill. Listening is aspect that important in learning English. Rost (2011) says that "there is no spoken language without listening". Linse (2005) also says that listening and reading is accept ability because focus from listening and reading is accept information from outside source. While speaking and writing is ability productive. Because from 
both of them information from listening and reading process become utterance and written but, listening is a skill that felt difficult to be mastered, because it needs more attention and concentration to comprehend the sounds (listening material). It can be said that listening is not a passive skill; the process of listening is a complex, listening is far more difficult than many people can imagine (Mee, 1990).

One of the factor that can determine success in dominate English is learning method. There are many media that can be used in listening and the good media is the media that can use to help student in reach aim of listening. The one of the media is song. The researcher consider that using song in teaching listening is very good and felt more interesting from the other activities because song is source language that authentic. This statement carried by Abdulrahman Al-Farid (2008) that songs in English can help teacher to create learning that creative, active and pleased. There is no limit time to using media song in teaching.

The student can use song in every time and everywhere they want until in a natural manner student have a contact with English and enjoy this process. So, the researcher interested in using song to improve students' listening skill. Because this media can make student interest in learning English especially for listening and can help student to know how to pronounce the world with the true way.

\section{LITERATURE REVIEW}

\section{Previous Related Study}

There are some studies related with the use song in learning listening. The first is, a research done by Umi Suryati“The Effectiveness of Using Song to Increase Students' Listening Skill of The Second Year Students of SMK N Ambai Kebumen in the Academic Year 2012/2013. The aim of this study is to find how effective of song in increasing the students' of SMK N 1 Ambai Kebumen. The researcher take two class for 66 students as the sample. The researcher colleted the data by using an achievements test and observation. The result of the research show that the mean of control group for the pre-test is 62.85 from the total score 2074 and the post-test is 71.76 from the total score 2368 , while the mean of experimental group for the pre-test is 66.09 from the total score 2181 and the posttest is 83.39 from the total score 2752 . The result of analysis indicates that in teaching listening using song is effective to make students increase the listening skill.

The second study is done by Sangadah, Nur (2010) entitled "The Effectiveness of Using Songs in Teaching English Articles ( An Experimental Research with the Third Graders of Elementary Purwokerto in the Academic Year of 2010 / 2011 ). The subjects of this study is the students at MIN Purwokerto in two classes thus were as experimental and control groups. The numbers of the subjects were 24 students in experimental group and 24 students in control group. This research 
used experimental method.The writer got a description that the results of test score of the experimental class which was given treatment using songs as media was 77.416 and control class which did not get treatment using songs as media that was 70.5. Based on the t-test with standard of significant $5 \%$, it was found count $t$ $=2.712$ with table $\mathrm{t}=2.00$. Consequently based the result, the process of learning English using songs as media is effective. The correlation between using songs in teaching English Articles (variable $\mathrm{X}$ ) and the effectiveness of using songs in teaching English Article (variable $\mathrm{Y}$ ) was found count $\mathrm{t}=2.712$ with table $\mathrm{t}=$ 2.00. Because count $t>$ table $t$. In conclusion, there is a real difference in score between those who using song as media and those who learn without using songs as media. In another word, the process of learning English articles using songs as media is effective.

The third researcher is Dito Setiyawan, entitled "The Effectiveness of Teaching Listening Comprehension Through English Song at Eleventh Grade of Elementary Purwokerto in Academic Year of 2010/2011. The aim of this research is to find out whether there is significant impovement of students' listening ability and two find out the problems feed by the students this reseearch used one group pre-test and post-tet design. The sample is eleventh grade. The data is take bypre-test, post-test and interview. The result show that students' mean score of post-test is 65.3, that is higher than pre-test 53.6 with the gain 10.5. Therefore, it could be concluded that English song could improve the students' listening comprehension better and overcome the problems the students faced during treatment.

Based on the explanation aboved, the researcher also interested using song like them above in teaching listening but in this study the researcher using song by experimental studies to know the effectiveness of using song teaching listening skill. In this study the researcher explain detail about the song in teaching listening.

\section{Some Pertinent Ideas}

\section{Listening Skill}

There are many definitions to define what is listening. First listening is an active, purposeful processing of making sense of what we hear (Helgesen, 2003, p.24). Rost (2011:279) states that listening is mental process of constructing meaning from spoken input. She also adds that listening is vital in the language classroom because it provides input for the learner. Without understanding input at the right level, any learning simply cannot begin. Listening is thus fundamental to speaking. Thomlinson (1998 cited by Ismail Cakir) defines listening includes "active listening", which goes beyond comprehending as understanding the message content as an act of emphatic understanding of the speaker. Listening is the ability to identify and understand what others are saying. It is also a complex activity and we can help students' comprehend what they hear by activating their 
prior knowledge. Furthermore, it will consider another way teachers may help the difficulty of listening by training students in different types of listening.

In listening we may find some of difficulties Listening is usually a hard skill to master by the students. The first reason is the student is does not have a text in front of them to look at if they do not understand the information from the teacher. The second reason is the accent and intonation of the native speaker which can make confused because each country has dialect and regional accent. According to Richards, common listening problems are:

1. Speaker speaks too fast.

2. Listeners listen word for word.

3. Listeners lack of cultural or background knowledge.

4. Speakers use too many unfamiliar words.

5. Listening takes too much effort and concentration.

6. Recordings are not always clear and are difficult to follow.

7. Speakers' accents are unfamiliar.

8. Tasks are too difficult.

9. Listeners cannot recognize words they know when they hear them. He also mentions the difficulty of listening factors:

1. Listeners' linguistic knowledge.

2. Knowledge of the co-text.

3. Background knowledge.

4. Learners' motivation and interest in the topic.

5. Cognitive load of the text (topic, text length, text type).

6 . Lexical density (ratio of the new words to know words).

7. Tasks.

Richards mentions that the problems are coming from some aspects such as students, media, and interest in doing the tasks. Efforts have to be done by the teacher to avoid these problems in the listening class materials. One problem is causing to another problems. For example if students lack of background knowledge, they will feel that the tasks are too difficult. This problem is affecting the students' motivation and materials. One problem is causing to another problems. For example if students lack of background knowledge, they will feel that the tasks are too difficult. This problem is affecting the students' motivation and interest in doing the tasks. Efforts have to be done by the teacher to avoid these problems in the listening class.

\section{Song}

According to Hornby (1990: 1133), song is a piece of music with words that is sung. Song is also a great language package that bundles culture, vocabulary, listening, grammar and a host of other language skills in just a few rhymes. Songs can also provide a relaxed lesson on a hot boring day. They can also form the basis for many lessons (Futonge, 2005). Almost everyone loves songs. It is a part of our language and life from before birth onwards. As a baby, we often hear our 
mother and father sing a song to deliver us sleep in the bedroom. When young children, we play, sing, and dance to a rhymes. As adolescents, we are consumes by the beat of popular songs artist in the world. As adults, we often hear song on television, movies, theater, and even nightly news. When we work, when we play, song is there to reinforce or every mood and emotion.

From explanation above, we are suggested to include songs in language learning as well. Songs had heard by the people in the world since they are born until died. So, listening to the songs has been a habitual and liked by everybody. Beside of that, by songs we can provide a relaxed lesson on a hot boring day.

\section{Factors Contributing to Listening Comprehension of Song}

The possibility of using songs in English as a foreign language class has been actively considering for the last two decades. It is considered because songs have many value of language. Orlova (2003), states that it is possible to suggest that among the methodological purposes with songs are used in class, it is possible to rank the following:

a. Practicing the rhythm, stress and the intonation patterns of the English language.

b. Teaching vocabulary, especially in the vocabulary reinforcement stage

c. Teaching grammar. In this respect songs are especially favored by teachers while investigating the use of the tenses.

d. Teaching speaking. For this purpose, songs and mainly their lyrics are employed as a stimulus for class discussion

e. Teaching listening comprehension

f. Developing writing skills. For this purpose a song can be used in a variety of ways.

According to Lynch (2008), there are three factors that contribute to listening comprehension of song, they are:

a. Use of new vocabulary, idioms and expressions - It needs to address the new material offered in each song. This includes grammar, vocabulary and usage.

b. Pronunciation and accent of the singer - Every native speaker doesn't pronounce or sing with the same accent. Students may be exposed to an accent which is outside the realm of what they might normally hear in context.

c. Use of new grammar and structure Song researchers and singers are notoriously "loose" when it comes to use of grammar, structure, pronunciation, stress and other language factors applied to songs. The teacher must prepare for this.

In additional, the use of songs in teaching and learning English as a foreign language is felt much needed. From the songs, we can learn many things such as vocabulary, grammar, listening, speaking, writing, and especially in listening. 


\section{METHOD}

\section{Design and Sample}

This research was conducted as an experimental study. An experiment is defined as "a situation in which one observes the relationship between two variables by deliberately producing a change in one and looking to see whether this alteration produces a change in the other (Suharsimi, 2006)". In other words, experiment is the way to find the causal relationship between two factors which are raised by the researcher in purpose by reducing or eliminating any distracting factors.

The subjects of this research are divided into two groups: experimental class which using songs and control class which without using songs. In this research, the method used by writer is quantitative method. It is quantitative because the data that is numeric and is analyze by using statistical computation.

\section{Population}

According to Arikunto (2006), population is all the subject of the research. In this research, the object of population is all the students (VIII A, VIII B and VIII C) in SMP N 11 Kabupaten Sorong. The student totally in this grade about 72students. Eight A there are 24 students, Eight B grade there are 24 students, while in eight C 24 students.

\section{The Procedure of the Research}

1. The researcher do an observation at SMP N 11 KabupatenSorong

2. The researcher chooses two class and divides into two groups (experimental class and control class) then researcher give the test, that it called pre-test both of groups.

3. After the researcher giving a test to both of groups, then the researcher giving treatments both of group. For experimental class using Song and for control class using conventional method.

4. After both of the classes are giving by technique or method. The researcher giving post- test for them.

5. The researcher should be compared score between experimental class and control class. Which one more effective in teaching listening skill. The result will be analyzed by using T-test formula to compare the students' mastery of listening skill.

\section{FINDINGS AND DISCUSSION}

In getting the data, the researcher used quantitative design. The sample of the research was took two classes at the second grade that consisted of control class (class VIII b) and experimental class (class VIII c). When the researcher was collecting the data, the researcher give the pre-test and post-test to both of class to 
compare the scores of pre-test before giving the treatment and post-test after giving the treatment. To know more information about it, the researcher formulated the problem in form of research questions which have to be answered by collecting data from the both of the class. Before doing treatment, the researcher gave the pre-test to both of class to know students ability in listening skill. The form of pre-test was fill in the blank the song. Number of the question were ten questions. And after that, the researcher doing treatment to both the class. For control class the researcher doing treatment without song and for experimental class the researcher doing treatment with song to know whether the song effective or not. And the researcher did post-test to know student ability.

The score of pre-test and post-test from the experimental class and control class which are collected by the researcher are shown by the table below:

Table 4.1.Result of Pre-test in Experimental Class ( ) and Control Class ( ) at the second grade of SMP N 11 Kabupaten Sorong

\begin{tabular}{|c|c|c|c|c|c|c|}
\hline \multirow{2}{*}{ No } & \multicolumn{2}{|c|}{ Pre-test Experimental } & \multirow{2}{*}{ No } & \multicolumn{2}{|c|}{ Pre-test Control } & \multirow{2}{*}{} \\
\cline { 2 - 3 } & & & & & & \\
\hline 1 & 50 & 2500 & 1 & 80 & 6400 & 4000 \\
\hline 2 & 40 & 1600 & 2 & 30 & 900 & 1200 \\
\hline 3 & 30 & 900 & 3 & 20 & 400 & 600 \\
\hline 4 & 60 & 3600 & 4 & 80 & 6400 & 4800 \\
\hline 5 & 50 & 2500 & 5 & 30 & 900 & 1500 \\
\hline 6 & 50 & 2500 & 6 & 70 & 4900 & 3500 \\
\hline 7 & 40 & 1600 & 7 & 40 & 1600 & 1600 \\
\hline 8 & 80 & 6400 & 8 & 40 & 1600 & 3200 \\
\hline 9 & 70 & 4900 & 9 & 20 & 400 & 1400 \\
\hline 10 & 80 & 6400 & 10 & 20 & 400 & 1600 \\
\hline 11 & 30 & 900 & 11 & 60 & 3600 & 1800 \\
\hline 12 & 20 & 400 & 12 & 60 & 3600 & 1200 \\
\hline 13 & 60 & 3600 & 13 & 70 & 4900 & 4200 \\
\hline 14 & 60 & 3600 & 14 & 60 & 3600 & 3600 \\
\hline 15 & 70 & 4900 & 15 & 80 & 6400 & 5600 \\
\hline 16 & 30 & 900 & 16 & 50 & 2500 & 1500 \\
\hline 17 & 30 & 900 & 17 & 30 & 900 & 900 \\
\hline 18 & 70 & 4900 & 18 & 30 & 900 & 2100 \\
\hline 19 & 40 & 1600 & 19 & 50 & 2500 & 2000 \\
\hline 20 & 70 & 4900 & 20 & 90 & 8100 & 6300 \\
\hline 21 & 30 & 900 & 21 & 70 & 4900 & 2100 \\
\hline 22 & 50 & 2500 & 22 & 60 & 3600 & 3000 \\
\hline 23 & 80 & 6400 & 23 & 30 & 900 & 2400 \\
\hline & & & & & & \\
\hline
\end{tabular}




\begin{tabular}{|c|c|c|c|c|c|c|}
24 & 20 & 400 & 24 & 80 & 6400 & 1600 \\
\hline$\sum$ & 1210 & 6970 & $\sum$ & 1250 & 76700 & 61700 \\
\hline Average & 50.417 & 2904,167 & Average & 52.083 & 3195.833 & \\
\hline
\end{tabular}

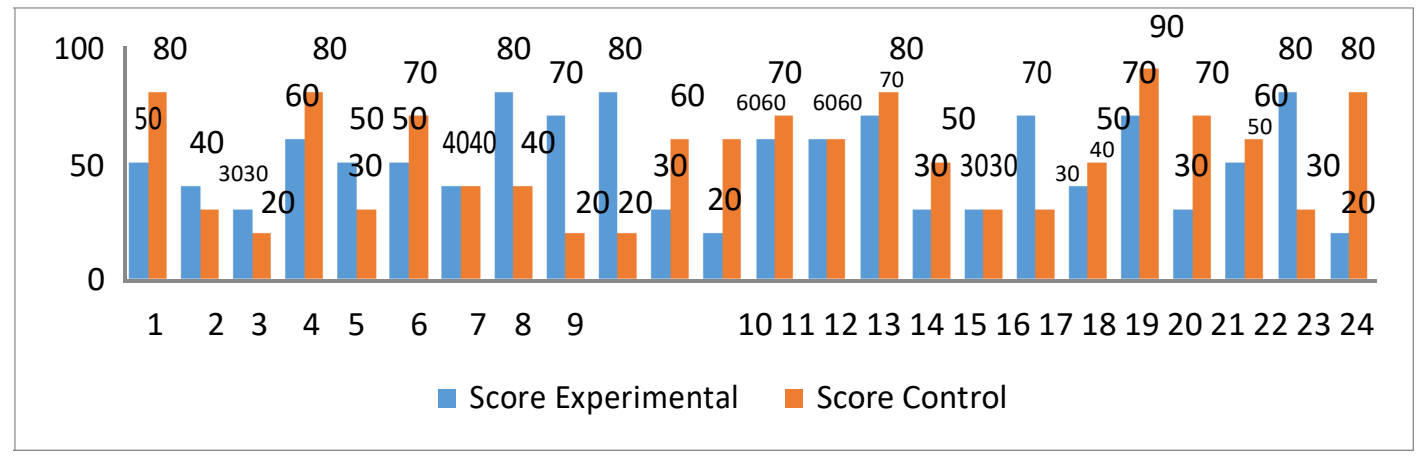

Chart 4.1 Diagram of Pre-test Experimental Class and Control Class

Based on the table and diagram 4.1.above the researcher can describes the lowest score of students in experimental group is 20 and the highest score is 80 with the mean score is 50.417 and in control class the lowest score is 20 and the highest score is 90 with the mean score 52.083. To make the reader easy see the researcher make table the students' score based on the criteria of evaluating listening bellow:

\subsection{Score Categories Experimental Group before treatment}

\begin{tabular}{|c|c|c|c|c|}
\hline No & Score & Categories & Frequency & Percentage \\
\hline 1 & $91-100$ & Excellent & 0 & $0 \%$ \\
\hline 2 & $81-90$ & Very Good & 0 & $0 \%$ \\
\hline 3 & $71-80$ & Good & 3 & $12.5 \%$ \\
\hline 4 & $61-70$ & Average & 4 & $16.67 \%$ \\
\hline 5 & $51-60$ & Poor & 3 & $12.5 \%$ \\
\hline 6 & $<50$ & Very Poor & 14 & $58.33 \%$ \\
\hline
\end{tabular}

Table above shows that 3 students with percentage $12.5 \%$ of 24 students are understand most of what was said/ instructed if it repeated, so make him slow in doing what is instructed, even sometimes wrong, 4 students with percentage $16.67 \%$ of 24 students are hardto follow what is instructed but still much or has instructions are carried out correctly,3 students with percentage $12.5 \%$ of 24 students arevery difficult to do as instructed, only a fraction are instructedand 14 students with percentage $58.33 \%$ from 24 students are unable to carry out what is instructed, though one instruction only.

Table 4.3. Score Categories Control Group before treatment 


\begin{tabular}{|c|c|c|c|c|}
\hline No & Score & Categories & Frequency & Percentage \\
\hline 1 & $91-100$ & Excellent & 0 & $0 \%$ \\
\hline 2 & $81-90$ & Very Good & 1 & $4.16 \%$ \\
\hline 3 & $71-80$ & Good & 4 & $16.67 \%$ \\
\hline 4 & $61-70$ & Average & 3 & $12.5 \%$ \\
\hline 5 & $51-60$ & Poor & 4 & $16.67 \%$ \\
\hline 6 & $<50$ & Very Poor & 12 & $50 \%$ \\
\hline
\end{tabular}

Table above shows that 1 student with percentage $4.16 \%$ of 24 students is Understand almost instruction despite there was repetition in certain parts, but it can do all the instruction correctly although some what slow, 4 students with percentage $16.67 \%$ of 24 students are understand most of what was said/ instructed if it repeated, so make him slow in doing what is instructed, even sometimes wrong, 3 students with percentage $12.5 \%$ of 24 students arehardto follow what is instructed but still much or has instructions are carried out correctly, 4 students with percentage $16.67 \%$ from 24 students are very difficult to do as instructed, only a fraction are instructed and 12 students with percentage $50 \%$ from 24 students are unable to carry out what is instructed, though one instruction only.

Based on the table above the researcher can make conclude that the score of students in experimental class is low then the score of student in control class before the researcher give treatment to students. Then, the researcher compared with the result of post-test after given treatment. The result of post-test experimental group and control group showed the table below:

Table 4.4 Result of Post-test in Experimental Class ( ) and Control Class ( ) at the second grade of SMP N 11 Kabupaten Sorong

\begin{tabular}{|c|c|c|c|c|c|c|}
\hline \multirow{2}{*}{ No } & \multicolumn{2}{|c|}{ Post-test Experimental } & \multirow{2}{*}{ No } & \multicolumn{2}{|c|}{ Post-test control } & \multirow{2}{*}{} \\
\cline { 2 - 3 } \cline { 5 - 6 } & & & & & \\
\hline 1 & 90 & 8100 & 1 & 80 & 6400 & 7200 \\
\hline 2 & 70 & 4900 & 2 & 50 & 2500 & 3500 \\
\hline 3 & 80 & 6400 & 3 & 50 & 2500 & 4000 \\
\hline 4 & 70 & 4900 & 4 & 70 & 4900 & 4900 \\
\hline 5 & 80 & 6400 & 5 & 60 & 3600 & 4800 \\
\hline 6 & 60 & 3600 & 6 & 90 & 8100 & 5400 \\
\hline 7 & 40 & 1600 & 7 & 60 & 3600 & 2400 \\
\hline 8 & 100 & 10000 & 8 & 70 & 4900 & 7000 \\
\hline 9 & 90 & 8100 & 9 & 40 & 1600 & 3600 \\
\hline 10 & 80 & 6400 & 10 & 40 & 1600 & 3200 \\
\hline 11 & 90 & 8100 & 11 & 80 & 6400 & 7200 \\
\hline 12 & 90 & 8100 & 12 & 50 & 2500 & 4500 \\
\hline 13 & 40 & 1600 & 13 & 80 & 6400 & 3200 \\
\hline
\end{tabular}




\begin{tabular}{|c|c|c|c|c|c|c|}
14 & 60 & 3600 & 14 & 70 & 4900 & 4200 \\
\hline 15 & 70 & 4900 & 15 & 80 & 6400 & 5600 \\
\hline 16 & 50 & 2500 & 16 & 70 & 4900 & 3500 \\
\hline 17 & 80 & 6400 & 17 & 30 & 900 & 2400 \\
\hline 18 & 90 & 8100 & 18 & 40 & 1600 & 3600 \\
\hline 19 & 90 & 8100 & 19 & 80 & 6400 & 7200 \\
\hline 20 & 80 & 6400 & 20 & 90 & 8100 & 7200 \\
\hline 21 & 90 & 8100 & 21 & 50 & 2500 & 4500 \\
\hline 22 & 70 & 4900 & 22 & 60 & 3600 & 4200 \\
\hline 23 & 80 & 6400 & 23 & 40 & 1600 & 3200 \\
\hline 24 & 50 & 2500 & 24 & 80 & 6400 & 4000 \\
\hline$\Sigma$ & 1790 & 140100 & $\Sigma$ & 1510 & 102300 & 61700 \\
\hline Average & 74.583 & 5837.5 & Average & 62.917 & 4262.5 & \\
\hline
\end{tabular}

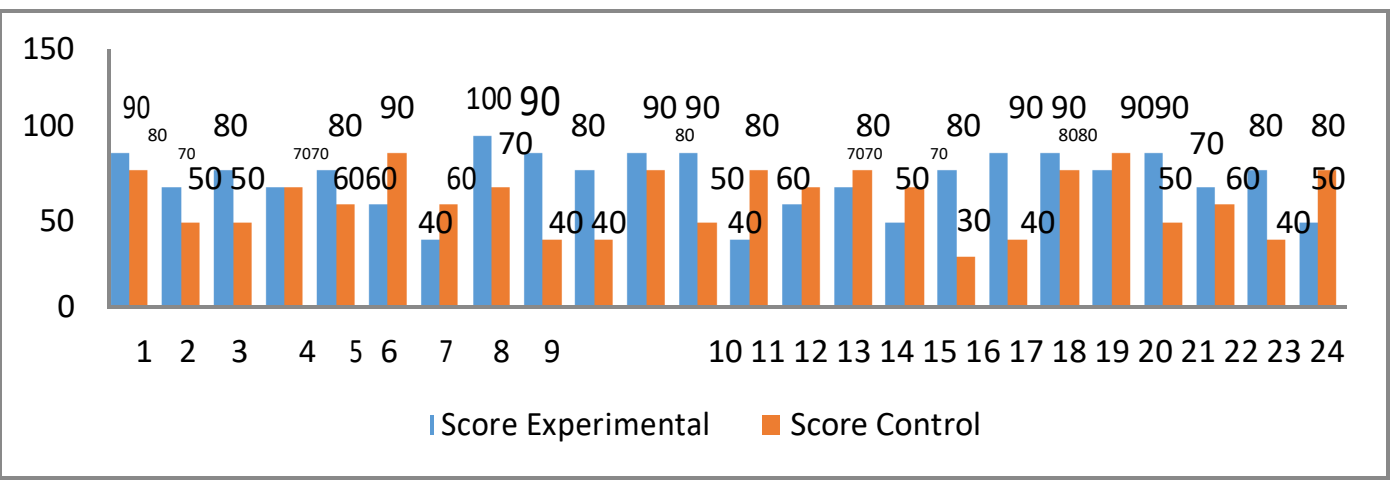

Chart 4.4 Diagram of Post-test Experimental and Control Class

From the table and chartabove the researcher can describes the lowest score of students in experimental group is 40 and the highest score is 100 with the mean score is 74.583 and in control class the lowest score is 30 and the highest score is 90 with the mean score 62.917 To make the reader easy see the researcher make table the students' score based on the criteria of evaluating listening bellow:

Table 4.5 Score categories of experimental class after treatment with song as a media

\begin{tabular}{|c|c|c|c|c|}
\hline No & Score & Categories & Frequency & Percentage \\
\hline 1 & $91-100$ & Excellent & 1 & $4.16 \%$ \\
\hline 2 & $81-90$ & Very Good & 7 & $29.17 \%$ \\
\hline 3 & $71-80$ & Good & 6 & $25 \%$ \\
\hline 4 & $61-70$ & Average & 4 & $16.67 \%$ \\
\hline 5 & $51-60$ & Poor & 2 & $8.33 \%$ \\
\hline 6 & $<50$ & Very Poor & 4 & $16.67 \%$ \\
\hline
\end{tabular}

From the table above it could be seen that 1 students with percentage $4.16 \%$ form 24 students is understanding instruction without understanding the difficulties that 
can do all the instruction in a way that is fast and precise, 7 students with percentage $29.17 \%$ from 24 students are Understand almost instruction despite there was repetition in certain parts, but it can do all the instruction correctly although some what slow, 6 students with percentage $25 \%$ from 24 students are understand most of what was said/ instructed if it repeated, so make him slow in doing what is instructed, even sometimes wrong, 4 students with percentage $16.67 \%$ from 24 students are hardto follow what is instructed but still much or has instructions are carried out correctly, 2 students with percentage $8.33 \%$ from 24 students very difficult to do as instructed, only a fraction are instructed, 4 students with percentage $16.67 \%$ from 24 students are unable to carry out what is instructed, though one instruction only.

Table 4.6 Score Categories of Control Class after treatment without song as a media

\begin{tabular}{|l|l|l|l|l|}
\hline No & Score & Categories & Frequency & Percentage \\
\hline 1 & $91-100$ & Excellent & 0 & $0 \%$ \\
\hline 2 & $81-90$ & Very Good & 2 & $8.33 \%$ \\
\hline 3 & $71-80$ & Good & 6 & $25 \%$ \\
\hline 4 & $61-70$ & Average & 4 & $16.67 \%$ \\
\hline 5 & $51-60$ & Poor & 3 & $12.5 \%$ \\
\hline 6 & $<50$ & Very Poor & 9 & $37.5 \%$ \\
\hline
\end{tabular}

From the table above it could be seen that 2 students with percentage $8.33 \%$ from 24 students are understand almost instruction despite there was repetition in certain parts, but it can do all the instruction correctly although some what slow, 6 students with percentage $25 \%$ from 24 students are understand most of what was said/ instructed if it repeated, so make him slow in doing what is instructed, even sometimes wrong, 4 students with percentage $16.67 \%$ from 24 students are hardto follow what is instructed but still much or has instructions are carried out correctly, 3 students with percentage $12.5 \%$ from 24 students are very difficult to do as instructed, only a fraction are instructed and 9 students with percentage $37.5 \%$ from 24 students are unable to carry out what is instructed, though one instruction only.

Based the both of table above the researcher can make conclusion that students' score is high in experimental group after the researcher did treatment using song in teaching listening skill meanwhile students' score is still low in control group after the researcher did treatment without using song in teaching listening skill.

\section{CONCLUSION}

After the researcher finished the chapters before, the researcher will draw some conclusions as the result of the study on the effectiveness of using in teaching Listening Skill at the second grade of SMP N 11 Kabupaten Sorong. Based on the hypothetical test and discussion of the data analysis in the chapter before, the 
conclusion can be seen that the teaching of teaching listening skill using songs are more effective at the second grade of SMP N 11 Kabupaten Sorong.

\section{References}

Arikunto, S. (2006). Dasar-Dasar Evaluasi Pendidikan (Edisi Revisi). Jakarta: Bumi Aksara.

Hornby, A.S. (1990). Oxford Advanced Learners Dictionary. Oxford: Oxford University Press.

Linse. (2005). Practical English Language Teaching: Young Learners. New York: Mcgraw Hill.

Rost. M. (2011). Teaching and Researching Listening. London: Pearson Education Limited.

Sugiyono. (2006). Metode Penelitian Pendidikan Pendekatan Kuantitatif, Kualitatif, Dan R\&D. Bandung: Alfabeta.

Lynch, M, L. (2008). Using Popular Song to Improve language Listening Comprehension Skills. Avaible on: http://ezinearticles.com/?UsingPopular-Songs-to-Improve-Language-Listening-ComprehensionSkills\&id=104984 [Desember 29, 2016]. 